Original Article

\title{
Effects of gender and grade on differences in physiotherapy students' interest and reasons for participating in overseas volunteer programs
}

\author{
Akira Kubo, RPT, PhD ${ }^{1 *}$, Ko Onoda, RPT, $\mathrm{PhD}^{1)}$, Yusuke Nishida, RPT, $\mathrm{PhD}^{2}$, \\ Kazuo Kurosawa, RPT, PhD ${ }^{3)}$, Masaharu Morita, RPT, $\mathrm{PhD}^{4)}$ \\ 1) Department of Physical Therapy, School of Health Science, International University of Health and \\ Welfare: 2600-1 Kitakanemaru, Ohtawara-shi, Tochigi 324-8501, Japan \\ 2) Department of Physical Therapy, School of Health Sciences at Narita, International University of \\ Health and Welfare, Japan \\ 3) Department of Physical Therapy, School of Health Science at Odawara, International University of \\ Health and Welfare, Japan \\ 4) Department of Physical Therapy, School of Health Sciences at Fukuoka, International University of \\ Health and Welfare, Japan
}

\begin{abstract}
Purpose] The purpose of the present study was to evaluate the gender and grade differences in interest and reasons associated with overseas volunteer participation among physiotherapy students using a cross-sectional survey. [Participants and Methods] The participants were 1,093 physiotherapy students who were enrolled at the International University of Health and Welfare's Ohtawara, Narita, Odawara, and Fukuoka campuses in 2017. A cross-sectional design was used to study the differences between gender and among undergraduate grade levels. The degree of interest and reasons associated with overseas volunteer participation were evaluated by a questionnaire survey using a four-point scale. [Results] Female students were significantly more interested and active in overseas volunteer participation than male students. As for participation by students' grades, significant differences were found in three items only among female students. [Conclusion] Female students were significantly more active at volunteering than male students. It was suggested that we need to encourage students to engage in overseas volunteer participation from the time of admission, especially female students. Key words: Overseas volunteers, Physical therapy student, Gender differences
\end{abstract}

(This article was submitted May 4, 2020, and was accepted Jun. 22, 2020)

\section{INTRODUCTION}

A definition for volunteering would be, "any activity in which time is given freely to benefit another person, group or organization"1). Volunteers are frequently members of civic or professional groups who have an interest in health in medically underserved areas. Such volunteers often include physicians, nurses, physical and occupational therapists, and other providers as well as students from these respective disciplines.

In medical education, there is an interest in global health ${ }^{2-4)}$. However, there are few studies from medical rehabilitation professionals, such as physical therapists, occupational therapists, or speech therapists, associated with interest in overseas volunteer participation (OVP). These studies were reported by the Japan Overseas Cooperation Volunteers in the Japan International Cooperation Agency (JICA) ${ }^{5,6}$.

The International University of Health and Welfare has been established the subject, "State of Health and Welfare of

*Corresponding author. Akira Kubo (E-mail: akubo@iuhw.ac.jp)

(C2020 The Society of Physical Therapy Science. Published by IPEC Inc.

(c) $(-)$ This is an open-access article distributed under the terms of the Creative Commons Attribution Non-Commercial No Derivacc. ${ }_{\mathrm{BY}} \mathrm{NC}_{\mathrm{ND}}$ tives (by-nc-nd) License. (CC-BY-NC-ND 4.0: https://creativecommons.org/licenses/by-nc-nd/4.0/) 
Foreign Countries", in the second year. It is a compulsory subject at the Narita and Fukuoka campuses and an elective subject at the Ohtawara and Odawara campuses. Students who have taken this course stay in a foreign country for almost two weeks during periods of vacation. It is necessary to understand the differences in gender and grades for interests in OVP.

The purpose of this study was to therefore evaluate, using a cross-sectional survey, the effects of gender and student grade on differences in the interest and reasons associated with OVP of physical therapy students (PTS).

\section{PARTICIPANTS AND METHODS}

A total of one thousand and ninety-three PTS participated in this study. They were enrolled at the International University of Health and Welfare's Ohtawara campus in Tochigi Prefecture, Narita campus in Chiba Prefecture, Odawara campus in Kanagawa Prefecture, and Fukuoka campus in Fukuoka Prefecture in 2017. There were 351 students from the first grade, 281 from the second grade, 246 from the third grade, and 215 from the fourth grade. Among them, 604 male students, and 489 female students. Twenty-nine students were excluded because of a lack of informed consent and absence. The study was approved by the institutional review board of the corresponding author's university (approval No. 2017-Ig-7).

A cross-sectional design was used to study differences between gender and among undergraduate grade levels in PTS. Interest and reasons associated with OVP were evaluated by a questionnaire survey using a four-point scale. Surveys were set for each grade in late September 2017.

The survey items in the interest and reasons referred to our previous study ${ }^{7)}$.

Data were analyzed using descriptive statistics and a $\chi^{2}$ test using SPSS for Windows (23.0 IBM Corporation). P values $<0.05$ indicated statistical significance.

\section{RESULTS}

A significant gender difference was observed in the degree of interest in OVP. However, a significant grade difference was only observed in female students (Table 1).

A significant gender difference was found in all items except the following: 2) I was invited by a friend or acquaintance in the reason for OVP. A significant grade difference was found only in female students for three items: 3) I want to help people: 7) I want to make it advantageous for employment or admission: and 8) I want to acquire language skills (Table 2).

\section{DISCUSSION}

In this study, the gender and grade differences in interest and reasons associated with OVP were evaluated in PTS using a cross-sectional survey.

A significant gender difference was observed in the degree of interest in OVP, and female students were more interested in OVP than male students.

In responses concerning the reasons for OVP, a significant gender difference was found in all items except one. Many positive answers regarding such reasons were also remarked among female students. A previous study by Edgar ${ }^{8}$, utilizing the Motivation and Engagement Scale-University/College (MES-UC), highlighted gender differences in academic performance of PTS, showing that males had, on average, significantly lower scores for planning, task management, and persistence and higher scores for disengagement. Watanabe ${ }^{9)}$ demonstrated the physical therapy activities of JICA volunteers. By April 2015, 478 physical therapists had been dispatched, and 296 (62\%) of them were female. Suda et al. ${ }^{10)}$ demonstrated that while female students were physically inferior to male students, the percentage of volunteers who wished to participate in snow removal was $29.8 \%$ among females, which was significantly higher than the rate of $13.0 \%$ among males.

Wilson $^{1)}$ stated that motivation to volunteer is driven either by the volunteer's intrinsic motives or by the context of the volunteering experience. Our results suggest that participation of PTS appears to be context-dependent and that employ-

Table 1. Differences in interests between male and female (\%) and among undergraduate grade levels (\%)

\begin{tabular}{|c|c|c|c|c|c|c|c|c|c|}
\hline & \multicolumn{4}{|c|}{ Male } & \multicolumn{4}{|c|}{ Female } & \\
\hline & $\begin{array}{c}\text { Very } \\
\text { interested }\end{array}$ & $\begin{array}{c}\text { Quite } \\
\text { interested }\end{array}$ & $\begin{array}{l}\text { Not very } \\
\text { interested }\end{array}$ & $\begin{array}{l}\text { Not at all } \\
\text { interested }\end{array}$ & $\begin{array}{c}\text { Very } \\
\text { interested }\end{array}$ & $\begin{array}{c}\text { Quite } \\
\text { interested }\end{array}$ & $\begin{array}{l}\text { Not very } \\
\text { interested }\end{array}$ & $\begin{array}{l}\text { Not at all } \\
\text { interested }\end{array}$ & \\
\hline Total & 15.5 & 42.4 & 35.0 & 7.2 & 18.8 & 52.4 & 26.6 & 2.3 & $\S$ \\
\hline 1st-year & 17.2 & 46.8 & 31.2 & 4.8 & 21.5 & 56.4 & 21.5 & 0.6 & \\
\hline 2nd-year & 15.1 & 37.1 & 37.7 & 10.1 & 21.2 & 51.7 & 25.4 & 1.7 & \\
\hline 3rd-year & 15.4 & 40.8 & 36.2 & 7.7 & 12.5 & 46.4 & 38.4 & 2.7 & \\
\hline 4th-year & 13.3 & 44.2 & 35.8 & 6.7 & 18.5 & 53.3 & 22.8 & 5.4 & \\
\hline
\end{tabular}

$\S_{\mathrm{p}}<0.05$, significant difference between male and female.

${ }^{*} \mathrm{p}<0.05$, significant difference among undergraduate grade levels in female. 
Table 2. Differences in reasons between male and female (\%) and among undergraduate grade levels (\%)

\begin{tabular}{|c|c|c|c|c|c|c|c|c|c|}
\hline & \multicolumn{4}{|c|}{ Male } & \multicolumn{4}{|c|}{ Female } & \\
\hline & $\begin{array}{c}\text { Strongly } \\
\text { agree }\end{array}$ & Agree & Disagree & $\begin{array}{l}\text { Strongly } \\
\text { disagree }\end{array}$ & $\begin{array}{c}\text { Strongly } \\
\text { agree }\end{array}$ & Agree & Disagree & $\begin{array}{l}\text { Strongly } \\
\text { disagree }\end{array}$ & \\
\hline \multicolumn{10}{|c|}{ I want to try it for myself } \\
\hline Total & 16.6 & 44.8 & 33.0 & 5.6 & 16.7 & 53.7 & 26.7 & 2.9 & $\S$ \\
\hline 1st-year & 16.8 & 45.8 & 33.0 & 4.5 & 16.8 & 54.0 & 27.3 & 1.9 & \\
\hline 2nd-year & 17.5 & 45.0 & 30.6 & 6.9 & 22.7 & 56.3 & 19.3 & 1.7 & \\
\hline 3rd-year & 15.9 & 36.5 & 41.3 & 6.3 & 12.6 & 48.6 & 34.2 & 4.5 & \\
\hline 4th-year & 15.8 & 51.7 & 27.5 & 5.0 & 13.6 & 55.7 & 26.1 & 4.5 & \\
\hline \multicolumn{10}{|c|}{ I was invited by a friend or acquaintance } \\
\hline Total & 3.4 & 32.9 & 51.3 & 12.4 & 4.2 & 40.0 & 46.1 & 9.6 & \\
\hline 1st-year & 3.9 & 30.6 & 52.2 & 13.3 & 6.2 & 33.5 & 49.1 & 11.2 & \\
\hline 2nd-year & 3.1 & 33.8 & 51.9 & 11.3 & 4.2 & 46.2 & 42.0 & 7.6 & \\
\hline 3rd-year & 3.1 & 29.1 & 54.3 & 13.4 & 1.8 & 42.3 & 42.3 & 13.5 & \\
\hline 4th-year & 3.3 & 39.2 & 45.8 & 11.7 & 3.4 & 40.9 & 51.1 & 4.5 & \\
\hline \multicolumn{10}{|c|}{ I want to help people } \\
\hline Total & 19.1 & 58.6 & 18.7 & 3.6 & 28.8 & 60.8 & 8.6 & 1.9 & $\S$ \\
\hline 1st-year & 20.7 & 60.9 & 16.2 & 2.2 & 41.0 & 52.8 & 5.0 & 1.2 & $*$ \\
\hline 2nd-year & 16.3 & 56.9 & 21.3 & 5.6 & 29.4 & 58.0 & 11.8 & 0.8 & \\
\hline 3rd-year & 18.0 & 57.0 & 21.9 & 3.1 & 15.3 & 72.1 & 10.8 & 1.8 & \\
\hline 4th-year & 21.7 & 59.2 & 15.8 & 3.3 & 22.7 & 64.8 & 8.0 & 4.5 & \\
\hline \multicolumn{10}{|c|}{ I want to understand a different culture } \\
\hline Total & 27.0 & 50.0 & 19.2 & 3.7 & 32.9 & 53.5 & 11.9 & 1.7 & $\S$ \\
\hline 1st-year & 31.7 & 48.3 & 17.8 & 2.2 & 38.3 & 51.9 & 9.3 & 0.6 & \\
\hline 2nd-year & 23.8 & 44.4 & 25.6 & 6.3 & 33.6 & 56.3 & 9.2 & 0.8 & \\
\hline 3rd-year & 23.4 & 54.7 & 18.8 & 3.1 & 23.4 & 56.8 & 17.1 & 2.7 & \\
\hline 4th-year & 28.3 & 55.0 & 13.3 & 3.3 & 34.1 & 48.9 & 13.6 & 3.4 & \\
\hline \multicolumn{10}{|c|}{ I want to study society } \\
\hline Total & 25.2 & 53.3 & 17.7 & 3.7 & 25.1 & 63.3 & 9.8 & 1.9 & $\S$ \\
\hline 1st-year & 27.8 & 53.9 & 15.6 & 2.8 & 32.3 & 57.1 & 9.9 & 0.6 & \\
\hline 2nd-year & 20.0 & 53.8 & 20.0 & 6.3 & 25.2 & 63.0 & 10.1 & 1.7 & \\
\hline 3rd-year & 23.4 & 53.1 & 20.3 & 3.1 & 14.4 & 71.2 & 11.7 & 2.7 & \\
\hline 4th-year & 30.3 & 52.1 & 15.1 & 2.5 & 25.0 & 64.8 & 6.8 & 3.4 & \\
\hline \multicolumn{10}{|c|}{ I want to protect the environment or cultural properties } \\
\hline Total & 10.4 & 46.1 & 37.8 & 5.8 & 10.0 & 51.8 & 35.9 & 2.3 & $\S$ \\
\hline 1st-year & 6.1 & 47.8 & 41.7 & 4.4 & 11.2 & 49.1 & 38.5 & 1.2 & \\
\hline 2nd-year & 12.5 & 42.5 & 37.5 & 7.5 & 11.8 & 52.1 & 34.5 & 1.7 & \\
\hline 3rd-year & 13.3 & 43.8 & 36.7 & 6.3 & 6.3 & 52.3 & 37.8 & 3.6 & \\
\hline 4th-year & 10.8 & 50.8 & 33.3 & 5.0 & 10.2 & 55.7 & 30.7 & 3.4 & \\
\hline \multicolumn{10}{|c|}{ I want to make advantageous for employment or admission } \\
\hline Total & 11.9 & 41.0 & 39.8 & 7.3 & 11.5 & 52.4 & 32.2 & 4.0 & $\S$ \\
\hline 1st-year & 13.9 & 43.3 & 37.8 & 5.0 & 16.8 & 53.4 & 26.1 & 3.7 & * \\
\hline 2nd-year & 12.5 & 42.5 & 37.5 & 7.5 & 11.8 & 59.7 & 26.1 & 2.5 & \\
\hline 3rd-year & 8.6 & 39.1 & 43.0 & 9.4 & 7.2 & 46.8 & 39.6 & 6.3 & \\
\hline 4th-year & 11.7 & 37.5 & 42.5 & 8.3 & 6.8 & 47.7 & 42.0 & 3.4 & \\
\hline \multicolumn{10}{|c|}{ I want to acquire language skills } \\
\hline Total & 29.6 & 44.4 & 21.6 & 4.4 & 29.6 & 51.9 & 16.3 & 2.3 & $\S$ \\
\hline 1st-year & 31.7 & 45.6 & 20.6 & 2.2 & 37.0 & 49.4 & 13.6 & 0.0 & $*$ \\
\hline 2nd-year & 30.6 & 44.4 & 18.8 & 6.3 & 31.9 & 52.6 & 13.4 & 1.7 & \\
\hline 3rd-year & 28.9 & 42.2 & 25.0 & 3.9 & 16.2 & 55.9 & 22.5 & 5.4 & \\
\hline 4th-year & 25.8 & 45.0 & 23.3 & 5.8 & 20.5 & 50.0 & 17.0 & 3.4 & \\
\hline
\end{tabular}

${ }_{\mathrm{p}}<0.05$, significant difference between male and female.

${ }^{*} \mathrm{p}<0.05$, significant difference among undergraduate grade levels in female. 
ment or admission advantages associated with volunteering opportunities and acquisition of language skills may be more important than the simple desire to volunteer.

A significant grade difference was found only among female students in terms of interest and reasons. High interest in participation and agreement with reasons were conspicuous among lower grades, including the first and second grades. Kubo et al. demonstrated that students who advanced to the third and fourth grades acquired expertise-specific knowledge and skills, preparation for clinical practice, and employment-related activities ${ }^{7}$. Therefore, we should encourage PTS and especially female students to engage in OVP from the time of admission.

There are limitations to this study, and our results may not be generalizable to other schools.

\section{Conflict of interest}

The authors declare no conflicts of interest in this work.

\section{REFERENCES}

1) Wilson J: Volunteering. Respir Med, 2010, 104: 849-857.

2) Khan OA, Guerrant R, Sanders J, et al.: Global health education in U.S. medical schools. BMC Med Educ, 2013, 13: 3. [Medline] [CrossRef]

3) Ehn S, Agardh A, Holmer H, et al.: Global health education in Swedish medical schools. Scand J Public Health, 2015, 43: 687-693. [Medline] [CrossRef]

4) Suzuki T, Nishigori H: National survey of international electives for global health in undergraduate medical education in Japan, 2011-2014. Nagoya J Med Sci, 2018, 80: 79-90. [Medline]

5) Shimura K, Kubo A: Characteristics of age-related changes in blood pressure, oxyhemoglobin saturation, and physique in Bolivians residing at different altitudes: presentation of basic data for health promotion. J Phys Ther Sci, 2019, 31: 807-812. [Medline] [CrossRef]

6) Shimura K, Kubo A: Influence of the altitude of their location of work on blood pressure, arterial oxygen saturation and symptoms of acute high-altitude illnesses - a simplified physical check up for Japan Overseas Cooperation volunteer in Bolivia during their stay in highland city-. J Int Univ Health Welf, 2016, 21: 13-17 (in Japanese).

7) Kubo A, Onoda K, Yara Y, et al.: Cross-sectional survey of physical therapy students associated with overseas volunteers. J Asi Reha Sci, 2018 , 1: 18-23.

8) Edgar S: Identifying the influence of gender on motivation and engagement levels in student physiotherapists. Med Teach, 2015, 37: 348-353. [Medline] [CrossRef]

9) Watanabe M: Activities of physical therapy in JICA volunteer. Rigakuryouhougaku, 2015, 42: 657-658 (in Japanese).

10) Suda T, Morita I, Katoh M: Determinants of motivation to participate in voluntary service of snow removal among college students. Japanese Society of Snow and Ice, 2006, 227-227 (in Japanese). 